\title{
Affixal Models of Expressing the Category of "Graduality" in the Adjectives of the Russian Language
}

\section{Baharloo Hadi ${ }^{1}$}

Assistant Professor, Tarbiat Modares University, Tehran, Iran.

\author{
Ahmadi Mireyla ${ }^{2}$ \\ Associate professor, Tarbiat Modares University,
}

Tehran, Iran.

\section{Sanjari Maryam ${ }^{3}$}

Master of Russian Language, Tarbiat Modares University,

Tehran, Iran.

(date of receiving: December, 2018; date of acceptance: October, 2019)

\begin{abstract}
This research paper is devoted to the study of the main affixal morphemes, which are used to express the functional semantic category of graduality in the adjectives of the Russian language. The article considers the category of graduality and its constituent parts (intensification and de-intensification) in Russian linguistics, and the semantic and derivational features of this category. In this work have been studied the affixal means of expressing the intensification and de-intensification of adjectives in Russian language. The analysis shows that affixal morphemes with the meaning of graduation in the Russian language are used most often to express intensification. The results of the analysis can be useful not only to students studying Russian, but also to researchers studying the relationship between functional semantic categories and word-formation means of expression of these categories.
\end{abstract}

Keywords: Adjective, Graduality, Intensity, Intensification, De-Intensification, Affixal Model.

1. Email:baharloo@modares.ac.ir

2. Email: mireyla@modares.ac.ir

3. Email: Maryam.sanjari71@gmail.com. 


\title{
Аффиксальные модели выражения категорииградуальности в прилагательных русского языка
}

\author{
Бахарлу Хади \\ Преподаватель, Университет Тарбиат Модарес, \\ Тегеран, Иран. \\ Ахмади Мирейла ${ }^{2}$ \\ Доцент, Университет Тарбиат Модарес, \\ Тегеран, Иран. \\ Санджари Марьям ${ }^{3}$ \\ Магистрант кафедры русского языка Университета Тарбиат Модарес, \\ Тегеран, Иран. \\ (дата получения: декабрь 2018 г.; дата принятия: октябрь 2019 г.)
}

\begin{abstract}
Аннотация
Данная статья посвящена изучению основных аффиксальных морфем выражения функционально-семантической категории градуальности в прилагательных русского языка. Для достижения цели работы были поставлены задачи рассмотрения категории градуальности и еe составляющих частей (интенсификация и деинтенсификация) в русской лингвистике, а также определение семантических и словообразовательных особенностей данной категории. Далее в работе изучены аффиксальные средства выражения интенсификации и деинтенсификации признака в прилагательных русского языка. Выбор темы, прежде всего, связан с малоизученностью аффиксальных морфем прилагательных со словообразовательным значением градуальности в русском языке. Новизна работы заключается в определении позиции, которую занимает каждая аффиксальная морфема прилагательных с градульным значением на шкале градуальности. Проведенный анализ показывает, что аффиксальные морфемы градуирования признака в русском языке больше всего употребляются для интенсификации. Результаты анализа могут быть полезными не только исследователям, изучающим взаимосвязь функционально-семантических категорий и словообразовательных средств выражения этих категорий, но и студентам, изучающим русский язык.
\end{abstract}

Ключевые слова: Имя Прилагательное, Градуальность, Интенсивность, Интенсификация, Деинтенсификация, Словообразовательная Модель.

1. Email:baharloo@modares.ac.ir

2. Email: mireyla@modares.ac.ir

3. Email: Maryam.sanjari71@gmail.com. 


\section{Введение}

Словообразование как особый раздел языкознания постоянно привлекает внимание не только лингвистов и исследователей, но и специалистов, изучающих методику преподавания иностранных языков. Этот интерес при изучении иностранного языка связан с потенциалом словообразования в расширении способности студентов для образования, понимания и использования новых языковых единиц в результате знакомства с разными морфемами и словообразовательными типами. Объектом рассмотрения в данной исследовательской работе является словообразовательный тип, в котором производное слово образуется от производящего прилагательного с помощью форманта со словообразовательным значением «градуальности».

Вопрос о градуальности прилагательных в русском языке исследовался некоторыми лингвистами (такими как З.Б. Долгих, С.М. Колесникова, К.А. Константинова, С.С. Кадысева и т.д.). Из их работ можно сделать вывод, что эта категория как качественно-количественная характеристика признака, предмета указывает на степень проявления качества, которая разделяется на интенсификацию (усилению) и деинтенсификацию (уменьшению) признака.

\section{Основная часть}

Понятийные категории можно рассматривать с разных точек зрения: логической, философской и психологической и лингвистической. Среди указанных подходов, за прошлые десятилетия особое значение приобрело их лингвистическое рассмотрение.

Как утверждает Л.М. Васильев типы семантических категорий очень разнообразны. Основные критерии их классификации - это степень абстрактности и самостоятельности, объем содержания и его внутренняя расчлененность, внешнее средство выражения содержания и характер связи с другими семантическими категориями. Л.М. Васильев среди наиболее 
абстрактных и логически самостоятельных уазывает на семантические категории предмета, признака, бытия, отношения, действия, состояния, количества, качества, пространства, времени и т.п. Он наряду с указанными наиболее абстрактными категориями называет менее абстрактные, в том числе семантические категории движения, места, направления, множества (множественности), величины, степени, каузативности, притяжательности, одушевленности и т.п., называемые обычно субкатегориями. В качестве примера он выделяет множественность, величина, мера, степень и собирательность как субкатегории количества; а локативность, директивность, объемность и протяженность как субкатегории пространства и т.д.

Л.М. Васильев, указывая на иерархический характер отношения между семантическими категориями (CK) и субкатегориями, пишет, что (во-первых, простые семантические категории входят нередко в сложные семантические категории, неоднородные по своему логическому содержанию. Во-вторых, многие семантические категории имеют релятивный характер, т.е. мыслятся только в связи с какими-то другими категориями. Например, СК степени (градуальности) всегда мыслится вместе с СК качества (очень прочный) или интенсивности (очень быстрый); СК движения - вместе с СК пространства; состояние предполагает носителя состояния (субъект); оценка всегда имеет в виду того, кто оценивает, и объект оценки и т.д. В-третьих, семантические категории образуют однородные по своему логическому содержанию группы, лежащие в основе соответствующих группировок функциональносемантических полей ) (Васильев 1990. 139-140)

Среди указанных категорий проблема изучения функциональносемантической категории градуальности и средств ее выражения в языке составляет основной предмет нашей исследовательской работы. Что касается истории работы, среди научных трудов, посвящённых рассмотрению слов со значением мера и степени и возраста можно указать на работы Е.И. Шегала, 
И.И. Туранского, А.А. Ховаланой, Э. Сепира, Д. Болинджера и др. (Долгих 2012. 22).

Простым примером категории градуальности в русском языке является степень сравнения. По Ю.П. Князеву (количественная оценка меры (степени проявления) признака является семантической основой степеней сравнения). Он на основе работы И.А. Мельчука (Мельчук 1998. 117) предлагает следующее обобщающее определение: (категорией степеней сравнения называется такая категория, граммемы которой характеризуют степень интенсивности данного свойства - либо по отношению к такому же свойству другого объекта или всех объектов, мыслимых в данной ситуации, либо по отношению к тому же свойству того же объекта, но в другой момент времени). Естественно, что данная категория предполагает только признакам, которые возможно градуировать (нарастать или убывать). В этой категории обычно выступают антонимы. Ясно, что прилагательные типа большой - маленький, широкий - узкий, хороший - плохой отличаются не выражением разных признаков, а степенью проявления разных значений одного и того же признака (Князев 2007. 179).

Качественно-количественная характеристика признака, предмета, предъявляемая в современном русском языке через семантику градуального признака (степени качества) и семантику мерительного отношения, как функционально-семантическая категория, имеет словообразовательные, морфологические, синтаксические способы выражения (Михайловна 2009: 7).

Как указывает З.Б. Долгих (одним из основных языковых уровней, представляющих и выражающих градуальную семантику, является лексический). Он, на основе определения С.М. Колесникова (2012), определяет градуальную лексику так (слова или сочетания слов, семантическая структура которых содержит градосему (сему меры и степени величины признака)» (Долгих 2012. 24). 
Как утверждает Е.А. Гордиенко среди разных частей «главенствующее место в выражении категории градуальности принадлежит качественным прилагательным, так как именно они обозначают такой признак, который проявляется в предмете в большей или меньшей степени). В качестве примера можно указать на прилагательное легкий (рис. 1).

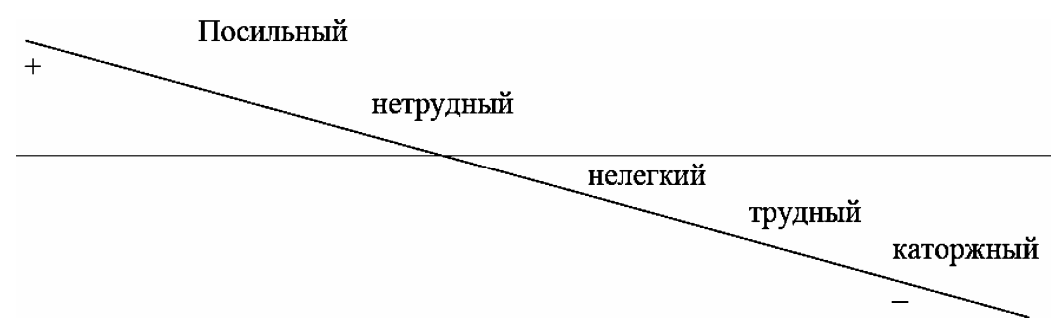

Рис. 1: Шкала градации признака для прилагательного «легкий»

«Качественные имена прилагательные обозначают признаки, которые легко поддаются градуированию: цвет, физические и психические свойства человека, размеры и т.д.) (Гордиенко 2005. 5-6).

\section{Составляющие субкатегории градуальности}

Семантическая категория градуальности разделяется на две основные сукатегории: интенсификация и деинтенсификация.

Интенсификация - это оценочная категория, которая служит для выделения какого-либо референта среди подобных референтов, и выделение такого рода происходит по субъективному представлению говорящего о мере признака или действия, отличающейся от нормальной (Родионова 2005.154 ). Деинтенсификация выражает меньшую степень проявления качества и играет существенную роль при выражении низкой степени интенсивности (Гвоздев 1958. 242. Шиловская 2007. 1).

По определению Н.Д. Федяевой (интенсификаторы, употребляемые со словами, называющими полярные проявления признака, могут изменять 
градуальную семантику этих слов и сдвигать их по шкале градации от полюсов к центру или к противоположному полюсу. Сравним: являясь обозначениями полярных проявлений признака, лексемы богатый - бедныцй в сочетании с интенсификаторами из группы усреднителей обозначают среднюю степень величины: довольно богат, достаточно беден; в сочетании с усилителями или уменьшителями градацию внутри полюса: очень богат,чрезвычайно беден, с отрицанием - антоним: совсем не богат, отнюдь небеден) (Федяева 2003. 28).

Градуирование признака можно показать в виде шкалы, которая называется «шкала градации», и представляет собой знаковую систему отображения степени проявления признака по отношению к точке отчета оси симметрии) (рис. 1). Точка отчета выражает нормальную усредненную степень признака, т.е. баланс сем меньше / больше.

Указанная шкала с обеих сторон ограничена минимальной и максимальной возможной степенью проявления признака и отражает способность качества изменять свои количественные характеристики при сохранении неразрывной связи противоположностей, то есть при сохранении качественного тождества (Федяева 2003. 25).

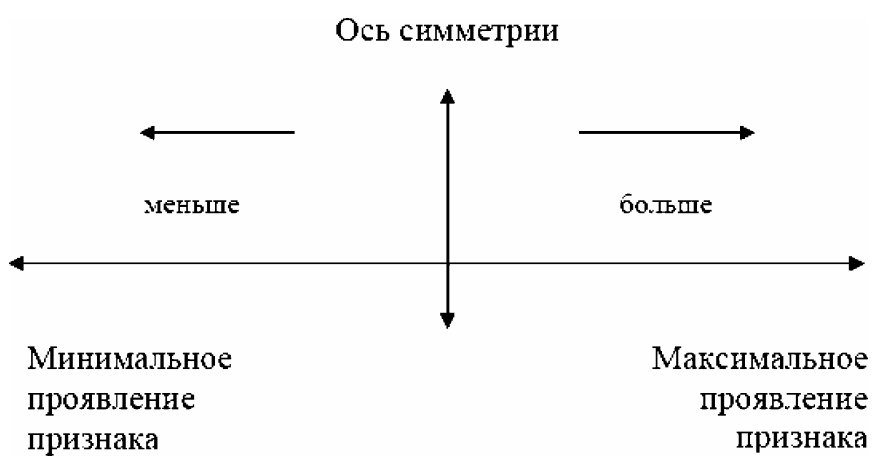

Рис 2. Шкала градации признака 


\section{Аффиксальные модели выражения градуальности прилагательных в русском языке}

Основные способы градуирования признака в русском языке можно разделить на две группы: эксплицитно выраженные и имплицитно выраженные. В первую группу входят два основных способа: выражение в слове (с помощью аффиксов) и вне слова (с помощью градуаторов как наречия, местоименные слова, частица и т.д., например, очень, совсем, почти, чymb-цуть).

Имплицитное градуирование признака «связано с тем, что градуальная семантика качественных прилагательных является характерным их признаком» (Усачева 2004. 31).

Первую группу составляют в основном мотивированные (производные) прилагательные, а вторую группу немотивированные (непроизводные).

Далее в связи с темой нашей работы рассматриваем основные аффиксальные морфемы, использующиеся в русском языке для интенсификации и деинтенсификации признака прилагательных русского языка. Корпус анализа составляет более 200 примеров из разных источников, в том числе: (Толковый словарь словообразовательных единиц русского языка» Т.Ф. Ефремовой (Ефремова 1996), „Современный русский язык. Словообразование) (Земская 2011), (Русский язык: морфемика, морфонология, словообразование) (Мусатов 2010), (Новый словарь русского языка. Толковословообразовательный» Т. Ф. Ефремовой (Ефремова 2000).

Для толкования аффиксальных морфем кроме вышеуказанных источников использованы книги «Современный русский литературный язык (Гвоздев 1958) и «Грамматическая семантика: русский язык в типологической перспективе» (Князев 2007). 


\section{Аффиксы интенсификации признака прилагательных}

На основе результатов нашего анализа можно сказать, что префиксальный, префиксоидальный и суффиксальный способы являются основными способами, использующимися в русском языке для интенсификации признака прилагательных. Далее в работе рассматриваются эти способы и средства их реализации в русском языке, а также определяется положение указанных формантов на шкале градации признака.

1. Префиксальный способ: основные средства интенсификации признака при префиксальном способе можно разделить на следующие:

за-: префикс за- обозначает признак, который характеризуется нахождением по той стороне или за пределами того, что названо мотивирующим словом или словосочетанием с ним, например: законченный (обладающий целостностью, полнотой, завершенный), запредельный (находящийся за пределами чего-л. или находящийся за пределами реальной действительности); заумный (излишне мудреный; недоступный пониманию кого-л.).

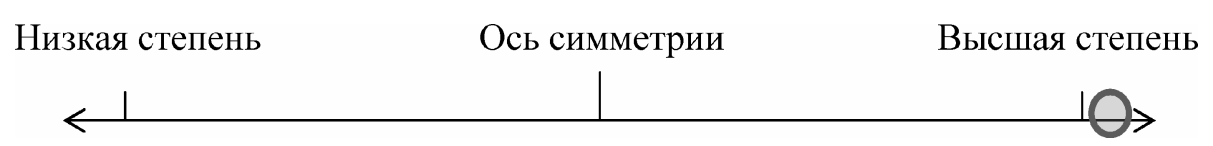

Рис. 3: Шкала градации приставки за-

$\boldsymbol{\mu a u - : ~ в ~ р я д ~ п р и с т а в о к - и н т е н с и ф и к а т о р о в ~ м о ж н о ~ в к л ю ч и т ь ~ п р и с т а в к у ~ н а и - , ~}$ которая при присоединении к превосходной степени выражает экспрессивное усиление и придает слову несколько архаический, книжный характер. Например: наивысший (самый высший), наикратчайший (самый короткий), наилучший (самый лучший), наименьший (самый малый), наиаккуратнейший (самый аккуратный), наиумнейший (очень умный), наибезобразнейший (очень безобразный). 


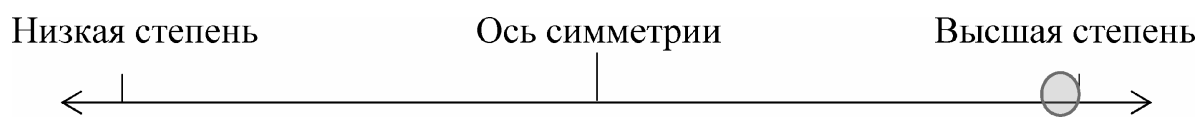

Рис. 4: Шкала градации приставкинаи-

npe-: по значению близка к наречиям меры высокой степени очень, чрезвычайно, и в новых образованиях нередко создает оттенок разговорной речи). Например: премильй (очень милый), прежирный (очень жирный), преважный (очень важный), препротивный (весьма противный), пренеприятный (очень неприятный), прегрубый (грубый в высшей степени), преотличный (отличный, превосходный).

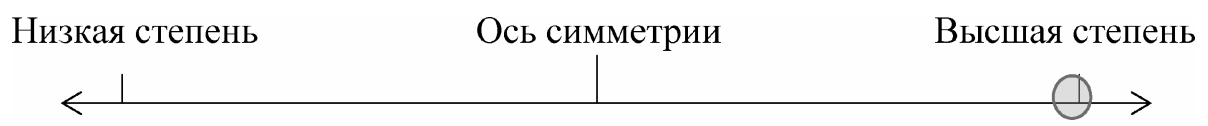

Рис. 5: Шкала градации приставкипре-

раз-: по значению синонимична приставке пре- и отличается от нее оттенком грубоватости. Например: paзвесёльй- очень весёлый (cp. превесёльй), разлюбезный (очень приятный, милый кому-л.), разудальій (такой, которому все нипочем; очень удалой), распрекрасныцй (очень прекрасный), расчудесный (очень чудесный), разнесчастный (очень несчастный), распотешный (очень потешный).

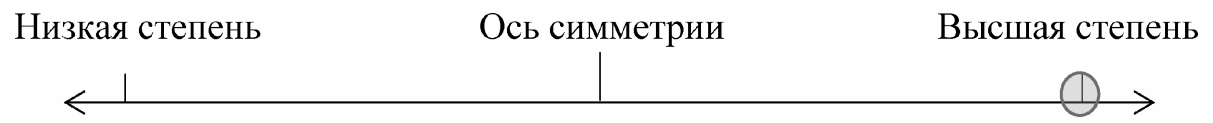

Рис. 6: Шкала градации приставки раз-

nо-: приставка-интенсификатор со значением незначительной интенсивности, например, покраснее -стать красным, краснее, приобрести красный цвет, поболее - немного больше, получще - немного лучше, пониже немного ниже и т.д. 


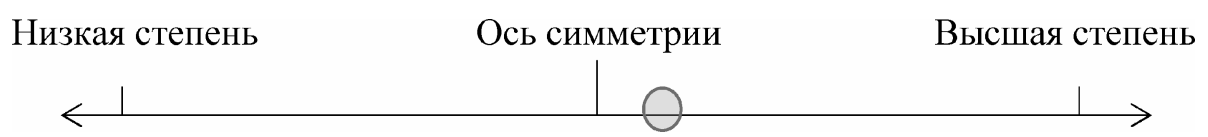

Рис. 7: Шкала градации приставкипо-

nере-: словообразовательная единица, образующая имена прилагательные со значением усиленного признака. известный-переизвестный (чрезмерно известный), переросльй (выросший выше других), переразвитый (чрезмерно развитый), перепуганный (находящийся в постоянном страхе, сильный испуг), перепрельй (испорченный от прения; перепревший), переполненнылй (наполненный, заполненный чем-л. сверх меры, с избытком), переобремененный (чрезмерно, слишком обременять), перенасыщенный (слишком сильно насыщенный, пропитанный чем-л.), перенаселенный (слишком густо населенный, с избытком населения) и т.п.

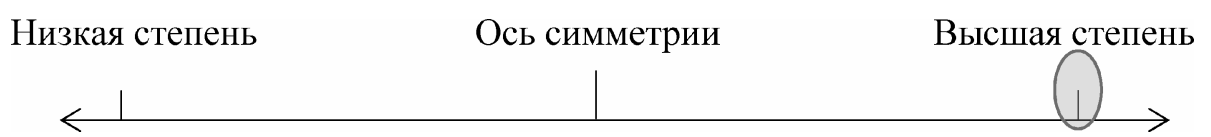

Рис. 8: Шкала градации приставки пере-

2. Префиксоидальный способ: В.Н. Мусатов определяет аффиксоиды как (словообразовательные морфемы, которые совмещают в себе как признаки корня, так и признаки аффикса. В зависимости от того, какую роль выполняют аффиксоиды (суффикса или префикса), они подразделяются на суффиксоиды и префиксоиды. Префиксоиды - это такие корневые морфемы, которые занимают в слове позицию префиксов и употребляются в их функции )(Мусатова 2010. 60-61).

Из основных префиксоидов русского языка, которые могут служить интенсификатором признака можно указать на следующие:

архи-: со значением высокой степени проявления признака. архисовременный(очень современный), архиважный (очень важный), 
архисложный (очень сложный), архипрозаический (очень прозаический), архиблагородный (очень благородный), архирациональный (очень рациональный), архиглупый (очень глупый), архинаучный (очень научный), архиопасный (очень опасный), архихудожественный (очень художественный).

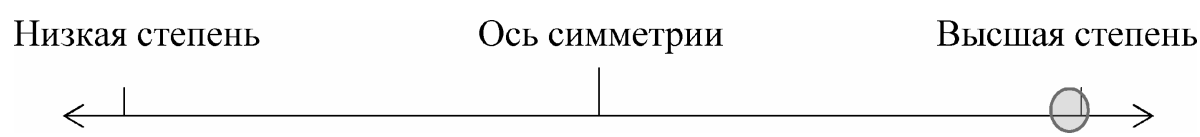

Рис. 9: Шкала градации префиксоида архи-

ультра-: этот аффикс образует прилагательные со значением признака, который характеризуется крайней, чрезмерной степенью проявления качества, названного мотивирующим слово, например, ультралевый (крайне левый), ультраправый (крайне правый), ультраоригинальный (предельно оригинальный), ультрасовременный (предельно современный), ультравысокий (предельно высокий), ультракороткийи (предельно короткий), ультрарадикальный (предельно радикальный).

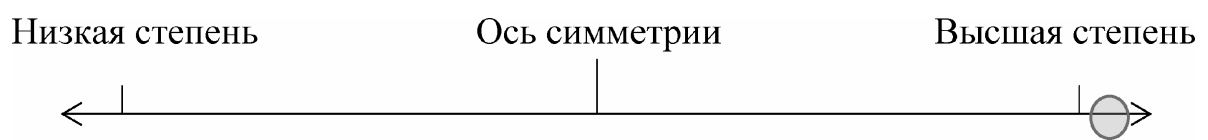

Рис. 10: Шкала градации префиксоида ультра-

cynep-: со значением высокой степени проявления признака и характеризуется высшей степенью проявления качества, названного мотивирующим словом: супермодный (очень модный), супертяжельй (очень тяжелый), суперсовременный (самый современный), супермощчный (очень мощный), суперновый (самый новый), супертрадиционный (очень традиционный), суперэффектный (очень эффектный). 


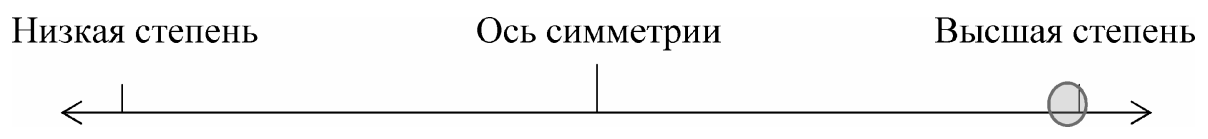

Рис. 11: Шкала градации префиксоида супер-

досто-: первая часть сложных слов с общим значением очень, весьма: достоуважаемый (весьма уважаемый, (много)уважаемый), достопочтенный (весьма почтенный).

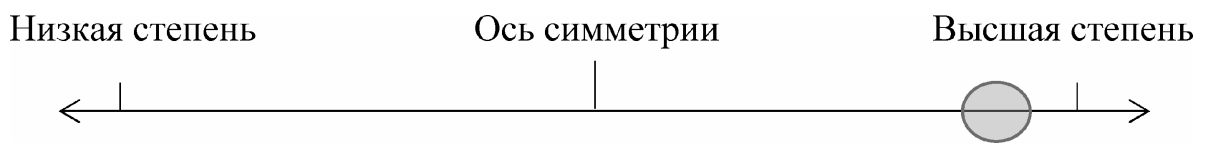

Рис. 12: Шкала градации префиксоида досто-

cверx-: со значением высокой степени проявления признака. Этот аффикс выражает высшую меру, указывая как бы на превышение обозначаемого качеств) и по значению аналогична ультра-сверхчеловеческий (превышающий обычные человеческие силы, возможности), сверхметкий (обладающий очень большой меткостью), сверхсильный (превышающий чьи-л. силы, возможности; непосильный), сверхдальний (значительно превышающий обычную, среднюю дальность чего-л.), сверхмощчный (обладающий очень большой мощностью), сверхопытный (не доступный опыту, находящийся за пределами опыта), сверхтвердый (отличающийся очень большой твердостью), сверхтяжельий (значительно превышающий обычную тяжесть), сверхразумный (находящийся за пределами постигаемого разумом), сверхъестественный (необычайный).

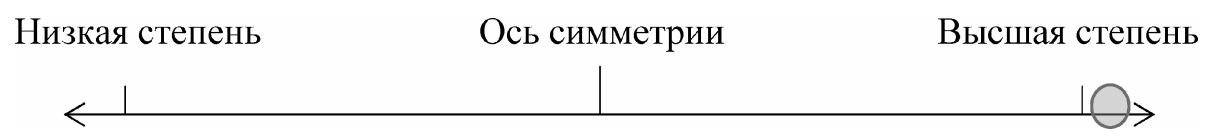

Рис. 13: Шкала градации префиксоида сверх-

чрез-: со значением высокой степени проявления признака: чрезмерный (превосходящий меру; слишком большой, слишком сильный), чрезвычайный 
(превосходящий обычную меру, не такой, как обычно; исключительный, очень большой, очень сильный).

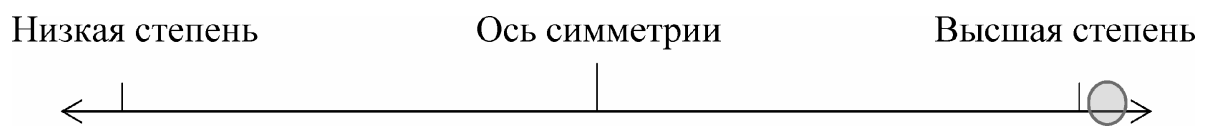

Рис. 14: Шкала градации префиксоида чрез-

небез- (небес-): отрицает отсутствие известного признака и на основе этого указывает на небольшую меру качества. Она по значению близка к суффиксу оват-). Например: небезвредный (причиняющий или приносящий некоторый вред; довольно вредный), небесполезный (имеющий или приносящий некоторую пользу; довольно полезный), небезызвестный (имеющий некоторую известность, достаточно известный), небезгрешный (не лишенный грехов; довольно греховный), небезынтересный (не лишенный некоторого интереса; довольно интересный), небезопасный (не лишенный опасности; довольно опасный), небезуспешный (имеющий некоторый успех; довольно успешный), небезразличныц̆ (вызывающий некоторый интерес, сочувствие, внимание), небезобидный (могущий причинить обиду, вред), небезосновательный (имеющий некоторые основания; достаточно основательный), небезвыгодный (приносящий некоторую выгоду; довольно выгодный).

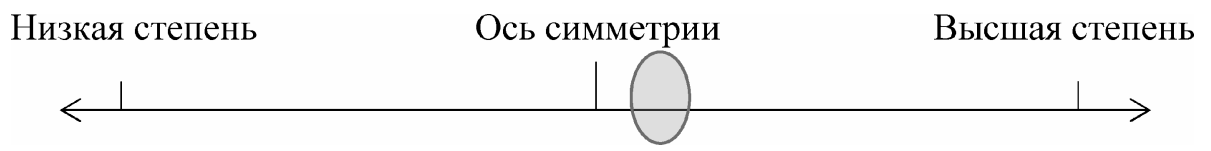

Рис. 15: Шкала градации префиксоида небез- (небес-)

экстра-: усиливает значение производящего прилагательного, и выражает признак, выходящий за пределы обычного: экстракардиальный (чрезвычайно кардиальный), экстраординарный (чрезвычайный, необыкновенный), экстрановыцй (чрезвычайно новый), экстрамодный (чрезвычайно модный). 


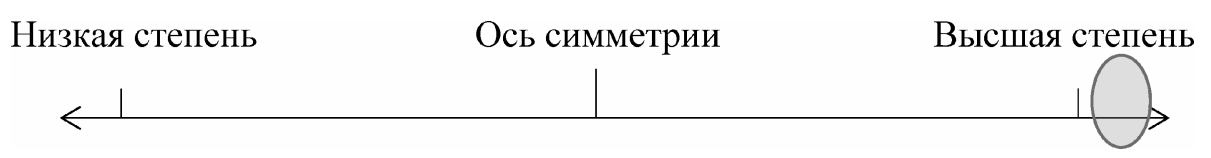

Рис. 16: Шкала градации префиксоида экстра-

3. Суффиксальный способ: среди основных суффиксовинтенсификаторов признака прилагательных в русском языке можно указать на следующие:

-ёхоньк- (-охоньк-), -ёщеньк- (-оченьк-), -еньк- (-оньк-): выражают предельно меру качества). Например: белехонький - белешенький (очень белый), чернехонький - чернешенький (очень черный), слабенький (очень слабый) - слабоватый, серенький - сероватый (очень серый), новехонький новешенький (очень, совсем новый), синенький (очень синий), добренький (очень добрый), живехонький (очень скоро, быстро), тихонький (очень тихий), умнёшенький (очень умный), легоменький (очень легкий), сухонький (совсем сухой), молоденький (очень молодой).

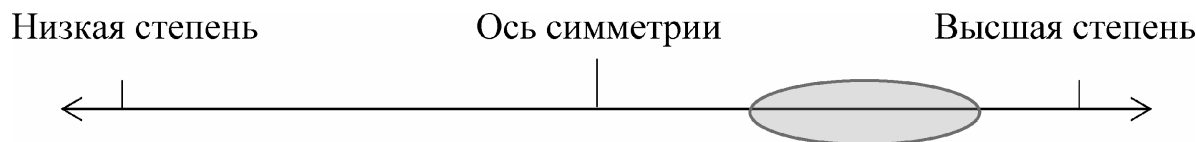

Рис. 17: Шкала градации суффиксов -ёхоньк- (-охоньк-), -ёшеньк- (-ошеньк-),-

еньк-(-оньк-)

-ученьк- (-юсеньк-): Формо- и словообразовательный суффикс, образующий имена прилагательные с усилительно-ласкательным значением малюсенький (очень маленький).

Низкая степень

Ось симметрии

Высшая степень

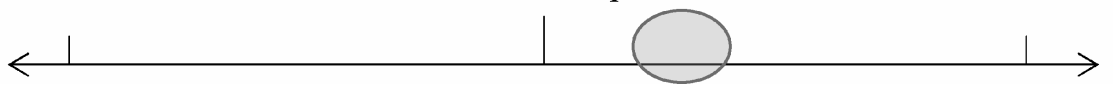

Рис. 18: Шкала градации суффикса юсеньк- 
-ущ- (-ющ-, -ящ-, -ащ-): выражает большую меру качества. Например: жирующий (очень жирный), худющий (самый плохой), чернящуий (очень черный), больщущий (очень большой; огромный), синящиий (очень синий), злющчий (очень злой), хитрющчий (очень хитрый), длиннющий (очень длинный).

Низкая степень



Рис. 19: Шкала градации суффикса -ущ- (-ющ-)

-ейш (ий)- / -айш (ий): выражает большую меру качества. Например: богатейший (очень богатый), старейший (очень старый), широчайший (очень широкий), строжайший (очень строгий), крупнейший (очень крупный).

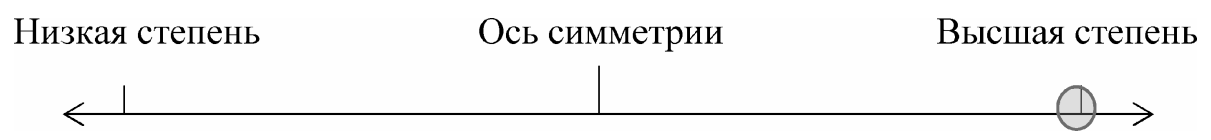

Рис. 20: Шкала градации суффикса -ейш (ий)- / -айш (ий)

\section{Словообразовательные способы выражения деинтенсификации прилагательных в русском языке}

Основными способами выражения деинтенсификации прилагательных (как и в случае интенсификации) являются префиксальный и суффиксальный способы, которые рассматриваются в следующей части.

1.Префиксальный способ: Из префиксов-деинтенсификаиоров русского языка можно указать на следующие:

без- (бес-): образует прилагательное антоним к прилагательным без этой приставки, выражая значения отсутствия признака, например: безбожный (отрицающий существование бога), безбрежный (не имеющий берегов, видимых границ), безудержный (ничем не удерживаемый), беспощзадный (не 
дающий пощады), бесценный (очень ценный; неоценимый), бесчисленный неисчислимый, многочисленный), бесспорный (не вызывающий возражений, сомнений, споров), безотраднылй (лишенный отрады, радости), бездельный (ленивый), безграмотный (не умеющий читать и писать; неграмотный), безопасный (не грозящий опасностью. Не причиняющий вреда), бесчеловечный (очень жестокий, безжалостный), безболезненныц (не вызывающий, не причиняющий боли), безаварийный (протекающий, происходящий без аварий), безбоязненный (не знающий боязни), безвкусный (не имеющий хорошего вкуса), безъядерный (свободный от производства, размещения и применения ядерного оружия, не имеющий ядра).

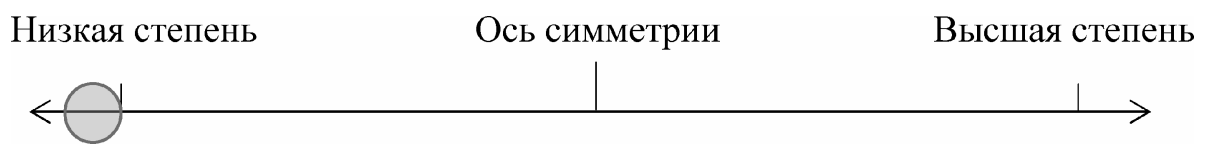

Рис. 21: Шкала градации приставки без- (бес-)

не-: отрицает наличие признака, образующий антонимы к прилагательным без этой приставки): несмельий (робкий), небольшой (маленький) - большой, нередкий (частый), нехороший (плохой), нетрудный (легкий), несложный (простой), невесомый (не имеющий веса, тяжести, очень легкий, имеющий незначительный вес), неограниченный (ограниченный), невозможный (неосуществимый, невыполнимый), невесельй (находящийся в грустном настроении; скучный), неверный (не соответствующий действительности, истине; ложный, ошибочный), нескромнылй (выражающий отсутствие скромности) и т.д.

Низкая степень Ось симметрии Высшая степень

Рис. 22: Шкала градации приставки не- 
a-: словообразовательная единица, образующая имена прилагательные со значением признака, который характеризуется отрицанием или отсутствием качества, близка по значению к приставкам без-, не-: аморальный (неотносящийся к морали, нарушающий мораль, безнравственный), алогичнылй (неотносящийся к логике, противоречащий логике, нелогичный), аритмичнылй (характеризующийся отсутствием или нарушением ритма; неритмичный), асинхронный (не совпадающий во времени, не одномоментный) и т.д.

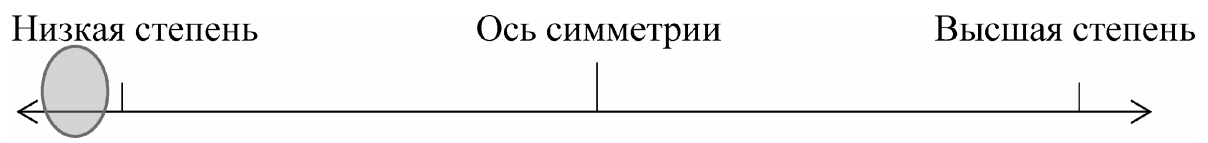

Рис. 23: Шкала градации приставки а-

полу-: единственный префиксоид, добавляющий к прилагательным значение неполноты признака (не вполне, почти): полуодетый (одеть не полностью), полуголый (почти голый),полуразрушенный (разрушенный не полностью), полубольной (недомогающий, не совсем здоровый), полугласный(не до конца гласный; неявный, неоткрытый), полуграмотныцй (едва умеющий читать и писать), полудетский (почти детский, почти как у ребенка), полудикий (до некоторой степени дикий), полудремотный (близкий к дремотному), полуживой (близкий к смерти, умирающий; полумертвый), полураздетый (почти раздетый, не совсем одетый), полуразбитый (почти лишенный сил (физических или моральных)), полупрозрачный (не совсем прозрачный), полупомешанный (не совсем нормальный, с признаками помешательства), полуофициальный (официальный до некоторой степени).

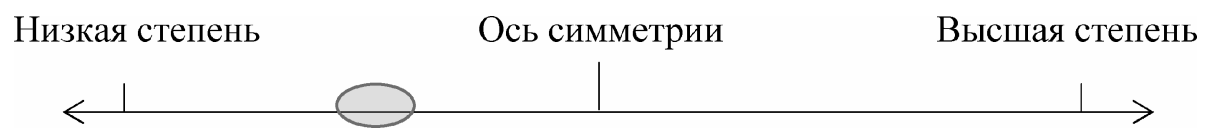

Рис. 24: Шкала градации префиксоида полу- 
2. Суффиксальный способ. В ряду суффиксов деинтенсификаторовможно указать на следующие:

-еньк- $\boldsymbol{u}$-оньк-: выражает уменьшительно-ласкательное значение в таких прилагательных, как сухонький (уменьш.-ласкат. к сухой), молоденький (немного молодой), старенький (немного старый) слабенький (немного слабый) - слабоватый.



Рис. 25: Шкала градации суффикса -еньк- и -оньк-

-оват- (-еват-): со значением ослабленного, неполного качества. Ю.П. Князев утверждает, что (в качестве еще одного компонента (категория сравнения и оценки» иногда выделяют модератив - обозначение ослабленной степени качества, реализуемое в таких прилагательных, как красноватый (в некоторой, в определенной степени красный, немного красный) $и$ беловатыци (приближающийся цветом к белому, имеющий белый оттенок)» (Князев 2007. 180). Например: желтый - желтоватый (немногожелтый, имеет желтый оттенок), сероватый (немного серый), синеватый (немного синий), жесткий жестковатый (немногожесткий), редкий - редковатый (немного редкий), грубоватый (немного грубый), сутуловатый (немного сутулый), глуповатый (недостаточно умный; недалекий), резковатый (немного резкий), светловатый (немного светлый), холодноватый(немного холодный), седоватый (немного седой), беловатый (приближающийся цветом к белому, имеющий белый оттенок),рыжеватый (немного рыжий), черноватылй (немного чёрный), хитроватый (немного хитрый) и т.д.

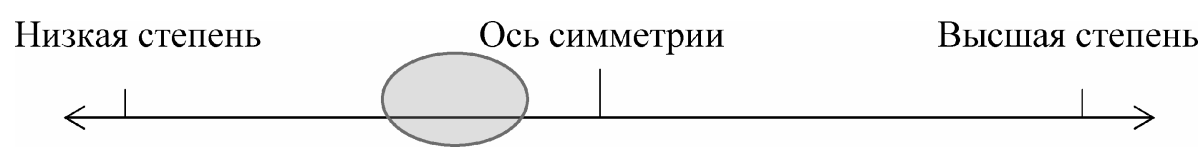

Рис. 26: Шкала градации суффикса -оват- (-еват-) 
Как показывает наш анализ, основную роль в градуировании признака играют предкорневые морфемы (18 морфем). Результаты анализа представлены в таблице 1.

Таблица 1. Аффиксальные морфемы грудирования признака в русском языке.

\begin{tabular}{|c|c|}
\hline Интенсификация & деинтенсификация \\
\hline \multicolumn{2}{|c|}{ Префикс } \\
\hline $\begin{array}{l}\text { общее количество: } 6 \\
\text { за- } \\
\text { наи- } \\
\text { пре- } \\
\text { раз- } \\
\text { по- } \\
\text { пере- }\end{array}$ & $\begin{array}{l}\text { общее количество: } 3 \\
\text { без-, бес- } \\
\text { не- } \\
\text { а- }\end{array}$ \\
\hline \multicolumn{2}{|c|}{ Префиксоид } \\
\hline $\begin{array}{l}\text { общее количество: } 8 \\
\text { архи- } \\
\text { ультра- } \\
\text { супер- } \\
\text { досто- } \\
\text { сверх- } \\
\text { чрез- } \\
\text { небез-, небес-: } \\
\text { эустра- }\end{array}$ & $\begin{array}{l}\text { общее количество: } 1 \\
\text { полу- }\end{array}$ \\
\hline \multicolumn{2}{|c|}{ Суффикс } \\
\hline $\begin{array}{l}\text { общее количество: } 4 \\
\text {-ёхоньк-, (-охоньк-),-ёшеньк-, } \\
\text { (-ошеньк-), -еньк- (-оньк-) } \\
\text {-юсеньк- } \\
\text {-ущ- (-ющ-, -ящ-, -ащ-) } \\
\text {-ейш (ий)- / -айш (ий) }\end{array}$ & $\begin{array}{l}\text { общее количество: } 2 \\
\text {-оват- (-еват-) } \\
\text {-еньк- (-оньк-) }\end{array}$ \\
\hline
\end{tabular}


Степень градуирования признака в прилагательных русского языка может меняться в зависимости от использованной аффиксальной морфемы. На рисунке 27 нарисована шкала градации признака прилагательных в общем виде.

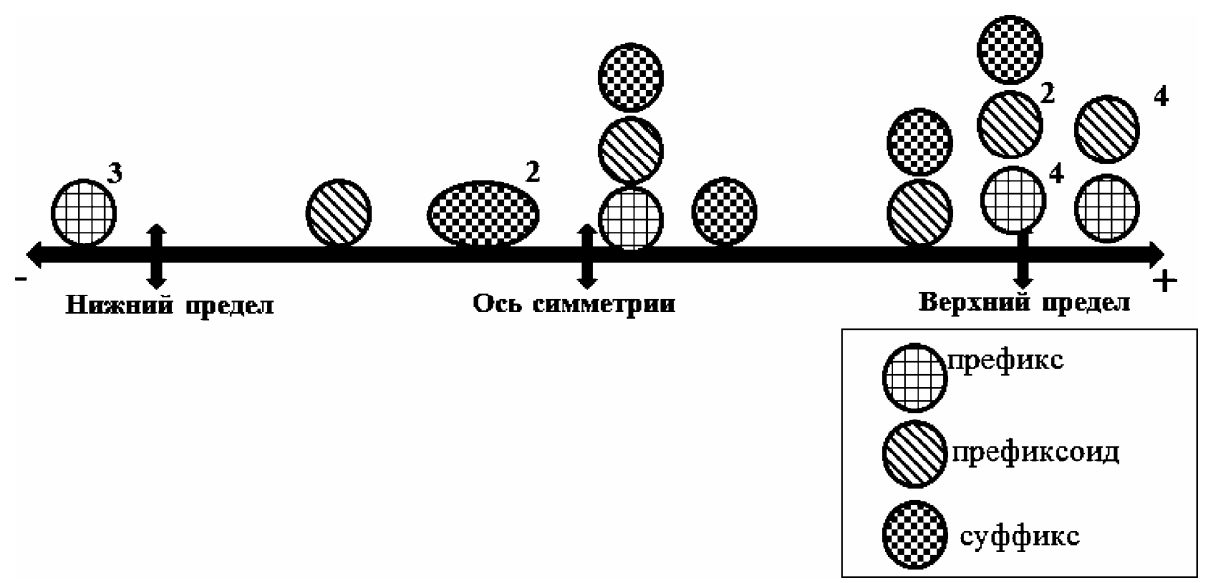

Рис 27. Сравнение степени градуирования признака в русском языке (числа обозначают количество морфем, выражающих данную точку градуирования)

\section{Заключение}

Анализ словообразовательных способов выражения значения градульности в прилагательных русского языка показывает, что в обеих субкатегориях интенсификации и деинтенсификации используются суффиксальный, префиксальный и префиксоидальный способы. В обоих разделах суффиксальный и префиксальный способы являются основными способами, но в субкатегории интенсификации более заметна роль префиксоидов.

В общем, в русском языке 24 морфемы служат для градуирования признака прилагательных: 18 морфем-интенсификаторов, и 6 морфемдеинтенсификаторов. При этом интересно наличие омонимичных морфем еньк-, оньк- с омонимичным значением интенсификации и деинтенсификации. 


\section{Литература}

1- Гвоздев А.Н. (1958), Современный русский литературный язык.-М., государственное учебно-педагогическое издательство министерства просвещения РСФСР.

2- Гордиенко Е.А. (2005), Категория интенсивности: опыт применения принципа унификации при исследовании антонимо-синонимических отношений в лексике современного русского языка // дисс. на соиск. уч. ст. кфн. Волгоград.

3- Долгих 3.Б. (2012), Функиионально-семантическая категория градуальности в системе современного португальского языка. -М. Вестник МГЛУ. Выпуск 10 (643).

4- Ефремова Т.Ф. (2000), Новый словарь русского языка. Толковословообразовательный.-М., Изд-во «Русский язык».

5- Ефремова Т.Ф. (1996), Толковый словарь словообразовательных единии русского языка.-М., Изд-во «Русский язык».

6- Земская Е.А. (2011), Современный русский язык. Словообразование.-М., Издво «Флинта: Наука».

7- Князев Ю.П. (2007), Грамматическая семантика: русский язык в типологической перспективе.-М., Изд-во «Язык и славянский культур.

8- Колесникова С.М. (2012), Синтагматические особенности наречий меры и степени и их градуальная функция в современном русском языке. -М. Вестник МГОУ. Серия "Русская филология". № 3.

9- Михайловна Р.Е. (2009), Категория градуальности в современных мордовских языках (на материале имени прилагательного) // дисс. на соиск. уч. ст. кфн. M.

10- Мусатов В.Н. (2010), Русский язык: Морфемика, морфонология, словообразование. -М., Изд-во «Флинта: Наука».

11- Родионова С.Е. (2005), Семантика интенсивности и ее выражение в современном русском языке // Проблемь функииональной грамматики: Полевые структуры. Под. Ред. А.В. Бондарко, С.А. Шубик -СПБ., Изд-во «Наука».

12- Федяева Н.Д. (2003), Языковой образ среднего человека в аспекте когнитивных категорий градуальности, оценки, нормы (на лексическом и текстовом материале современного русского языка) // дисс. на соиск. уч. ст. кфн. ОМСК.

13- Шиловская Л.В. (2007), Особенности деинтенсификации действия, выраженного глаголом и именем существительным в современном франиузском языке. Вестник Санкт-петербургского университета. Сер. 9.

14- https://ru.wiktionary.org 


\section{Bibliography}

1- Gvozdev A.N. (1958), Sovremennyj russkij literaturnyj jazyk. -M., gosudarstvennoe uchebno-pedagogicheskoe izdatel'stvo ministerstva prosveshhenija RSFSR.

2- Gordienko E.A. (2005), Kategorija intensivnosti: opyt primenenija principa unifikacii pri issledovanii antonimo-sinonimicheskih otnoshenij $v$ leksike sovremennogo russkogo jazyka // diss. na soisk. uch. st. kfn. Volgograd.

3- Dolgih Z.B. (2012), Funkcional'no-semanticheskaja kategorija gradual'nosti v sisteme sovremennogo portugal'skogo jazyka. -M. Vestnik MGLU. Vypusk 10 (643).

4- Efremova T.F. (2000), Novyj slovar' russkogo jazyka. Tolkovo-slovoobrazovatel'nyj .-M., Izd-vo «Russkij jazyk».

5- Efremova T.F. (1996), Tolkovyj slovar' slovoobrazovatel'nyh edinic russkogo jazyka.-M., Izd-vo «Russkij jazyk».

6- Zemskaja E.A. (2011), Sovremennyj russkij jazyk. Slovoobrazovanie.-M., Izd-vo «Flinta: Nauka».

7- Grammaticheskaja semantika: russkij jazyk v tipologicheskoj perspektive.-M., Izdvo «Jazyk i slavjanskij kul'tur.

8- Kolesnikova S.M. (2012), Sintagmaticheskie osobennosti narechij mery $i$ stepeni $i$ ih gradual'naja funkcija $v$ sovremennom russkom jazyke. -M. Vestnik MGOU. Serija "Russkaja filologija". No 3.

9- Mihajlovna R.E. (2009), Kategorija gradual'nosti v sovremennyh mordovskih jazykah (na materiale imeni prilagatel'nogo) // diss. na soisk. uch. st. kfn. -M.

10- Musatov V.N. (2010), Russkij jazyk: Morfemika, morfonologija, slovoobrazovanie.-M., Izd-vo «Flinta: Nauka».

11- Rodionova S.E. (2005), Semantika intensivnosti i ee vyrazhenie v sovremennom russkom jazyke // Problemy funkcional'noj grammatiki: Polevye struktury. Pod. Red. A.V. Bondarko, S.A. Shubik-SPB., Izd-vo «Nauka».

12- Fedjaeva N.D. (2003), Jazykovoj obraz srednego cheloveka $v$ aspekte kognitivnyh kategorij gradual'nosti, ocenki, normy (na leksicheskom i tekstovom materiale sovremennogo russkogo jazyka) // diss. na soisk. uch. st. kfn. OMSK.

13- Shilovskaja L.V. (2007), Osobennosti deintensifikacii dejstvija, vyrazhennogo glagolom i imenem sushhestvitel'nym v sovremennom francuzskom jazyke. Vestnik Sankt-peterburgskogo universiteta. Ser. 9.

14- https://ru.wiktionary.org

\section{HOW TO CITE THIS ARTICLE}

Бахарлу Х., Ахмади М. \& Санджари М. (2020). Affixal

Models of Expressing the Category of "Graduality" in the

Adjectives of the Russian Language. Issledovatel'skiy Zhurnal

Russkogo Yazyka I Literatury, 8(1), 175-197.

DOI: $10.29252 /$ iarll.15.175

URL: http://www.journaliarll.ir/index.php/iarll/article/view/115

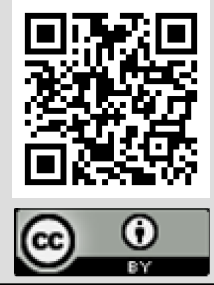




\title{
مدلهاى وندى بيان مقولهُ "درجهبندى" در صفات زبان روسى
}

 \\ استاديار گروه زبان روسى دانشگاه تربيت مدرس،

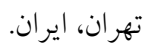 \\ ميريلا احمدى \\ دانشيار گروه زبان روسى دانشگاه تربيت مدرس، مئل

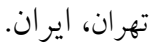 \\ مريم سنجرى \\ كارشناس ارشد زبان روسى، دانشخاه تربيت مدرس،

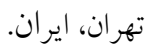

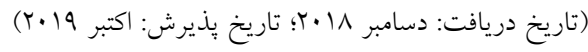

اين مقاله به بررسى تكوازهاى وندى اصلى كه در زبان روسى براى بيان مقولهُ درجهبنـدى

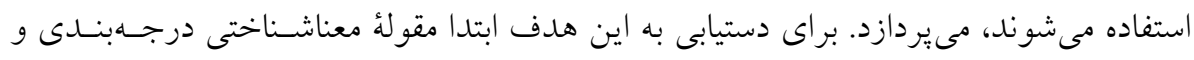

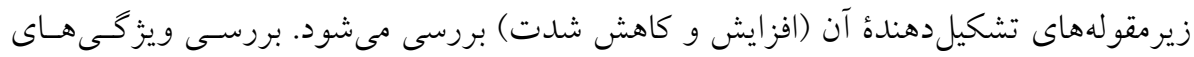

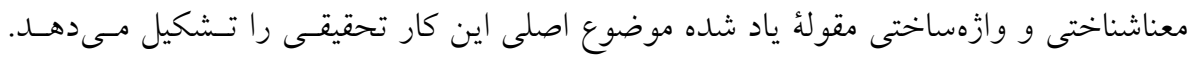

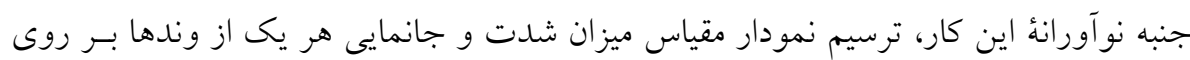

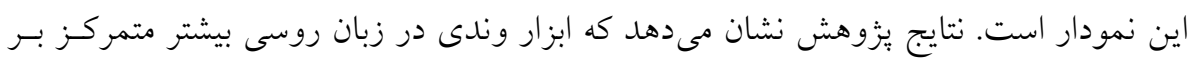

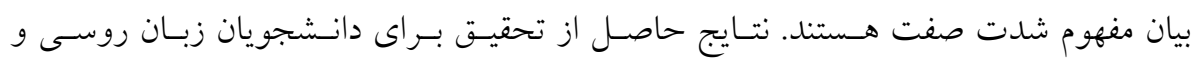
يزوهشخران حوزه مقولههاى معنايى مناسب خور اهل بود.

وازگًان كليدى: صفت، درجهبندى، شدت، افزايش شدت، كاهش شدت، روش وازهسازى.

1. E-mail: baharloo@modares.ac.ir

2. E-mail: mireyla@modares.ac.ir

3. E-mail: Maryam.sanjari71@gmail.com. 